\title{
Dehydrated cashew apple meal in the feeding of growing rabbits
}

\section{Farelo do pseudofruto do caju desidratado na alimentação de coelhos em crescimento}

\author{
Thalles Ribeiro Gomes ${ }^{1 *}$; Ednardo Rodrigues Freitas ${ }^{2}$; Pedro Henrique Watanabe ${ }^{2}$; \\ Maria Elizimar Felizardo Guerreiro²; Amanda da Rocha Sousa ${ }^{3}$; Ana Carolina \\ Sampaio Ferreira ${ }^{3}$
}

\begin{abstract}
Two trials were conducted aiming to determine the chemical composition, the digestibility of nutrients and energy from dehydrated cashew apple meal, as well as to evaluate the effects generated by including increasing levels $(0,10,20,30,40$ and $50 \%)$ of this ingredient in growing rabbit feed, on performance, carcass characteristics and economic evaluation. In the digestibility trial, were used 24 rabbits with 55 days of age, distributed in a completely randomized design with two treatments and twelve repetitions, being one reference feed and the other test feed, composed by $70 \%$ of the reference feed and $30 \%$ DCAM. The coefficients of the dry matter digestibility, crude protein and gross energy of the DCAM were, respectively, $67.79 ; 30.03$ and $48.61 \%$. The digestible dry matter, digestible protein and digestible energy, based on dry matter, were, respectively, $59.55 \% ; 4.76 \%$ and $2,119.66 \mathrm{kcal} / \mathrm{kg}$. In the second trial, 120 mixed breed rabbits were used, with an average of 45 days of age and weight $1143 \pm 153 \mathrm{~g}$. The animals were distributed in a completely randomized design, with six treatments and ten repetitions with two rabbits of the same sex per cage. It was observed that the inclusion of DCAM did not affect $(\mathrm{P}>0.05)$ the feed intake, but reduced $(\mathrm{P}<0.05)$ the feed conversion efficiency, as well as a linear reduction in carcass yield. A quadratic effect on daily weight gain and the ratio meat/bone was observed, with better inclusion level estimated at 25.31 and $24.65 \%$, respectively. The inclusion of DCAM linearly improved economic viability to the level of $50 \%$, however not to harm the weight gain and the ratio meat/bone, it is recommended to include up to $25 \%$.
\end{abstract}

Key words: Alternative food. Anacardium occidentale L.. Cashew pulp. Economic analysis. Oryctolagus cuniculus. Productive yield.

\section{Resumo}

Dois ensaios foram conduzidos com o objetivo de determinar a composição química, a digestibilidade dos nutrientes e da energia do farelo do pseudofruto do caju desidratado (FPCD), bem como avaliar os efeitos da inclusão de níveis crescentes $(0,10,20,30,40$ e 50\%) deste ingrediente em rações para coelhos em crescimento, sobre o desempenho, características de carcaça e avaliação econômica. No ensaio de digestibilidade foram utilizados 24 coelhos com 55 dias de idade, distribuídos em um delineamento inteiramente casualizado com dois tratamentos e doze repetições, sendo uma ração referência e outra ração teste, composta por $70 \%$ da ração referência e 30\% de FPCD. Os coeficientes de digestibilidade

${ }^{1}$ Pós-Doutorando, Departamento de Zootecnia, Universidade Federal do Ceará, UFC, Fortaleza, CE, Brasil. E-mail: thalleszoo@ yahoo.com.br

2 Profs., Departamento de Zootecnia, UFC. Fortaleza, CE, Brasil. E-mail: ednardo@ufc.br; pedrowatanabe@ufc.br; elizimar@ ufc.br

${ }^{3}$ Discentes, Curso de Mestrado do Programa de Pós-Graduação em Zootecnia, UFC, Fortaleza, CE, Brasil. E-mail: amandarocha1993@gmail.com; carolinaanasampaio@yahoo.com.br

* Author for correspondence 
da matéria seca, proteína bruta e energia bruta do FPCD foram, respectivamente, 67,79; 30,03 e 48,61\%. Os teores de matéria seca digestível, proteína digestível e energia digestível, com base na matéria seca, foram, respectivamente, $59,55 \% ; 4,76 \%$ e $2.119,66 \mathrm{kcal} / \mathrm{kg}$. No segundo ensaio foram utilizados 120 coelhos mestiços, com média de 45 dias de idade e peso de $1143 \pm 153 \mathrm{~g}$. Os animais foram distribuídos em um delineamento inteiramente casualizado, com seis tratamentos e dez repetições com dois coelhos do mesmo sexo por gaiola. Observou-se que a inclusão do FPCD não influenciou $(\mathrm{P}>0,05)$ o consumo de ração, porém promoveu uma piora $(\mathrm{P}<0,05)$ na conversão alimentar, bem como uma redução linear no rendimento de carcaça. Observou-se efeito quadrático no ganho diário de peso e na relação carne/ osso, com o melhor nível de inclusão estimado em 25,31 e $24,65 \%$, respectivamente. A inclusão do FPCD melhorou linearmente a viabilidade econômica até o nível de $50 \%$, entretanto para não prejudicar o ganho de peso e a relação carne/osso, recomenda-se incluir até $25 \%$.

Palavras-chave: Alimento alternativo. Anacardium occidentale L.. Análise econômica. Rendimento produtivo. Oryctolagus cuniculus. Polpa de caju.

\section{Introduction}

In the animal breeding as a business activity, the cost with food becomes high due to the corn dependence, soybean bran and especially alfalfa hay, since the inclusion of which rabbit feed aims to meet the requirements in fiber, however may represent over $40 \%$ of the total cost of food in the growth phase (RETORE et al., 2010), depending on the region. This demonstrates the need to evaluate alternative sources for this primary material, aiming, mainly, the knowledge of their nutritional value and the optimization of its use in the diets of these animals.

Considering the bromatological composition, some agroindustrial residues are potential substitutes for alfalfa hay or even as a main source of fiber in the diet, because of the composition of fibrous carbohydrates, and its use also contributes greatly to reducing the environmental impact that this residue entails when dumped inappropriately in the environment (LOUSADA JÚNIOR et al., 2006). Among these residues, in supply conditions, there is the residue of the pseudo fruit cashew, obtained after the extraction of the cashew juice for human consumption, being also used pseudo fruits discarded by industry or those that were not used during the cashew nuts harvest (LOPES et al., 2005). However, due to its elevated humidity level dehydration is necessary for the humid pomace to reach a humidity level that enables the grinding and conservation of this residue (TELES et al., 2010).
Due to the variations regarding the origin of the primary material used and the different processes, it is observed that the pseudo fruit cashew meal may present variations in its bromatological composition (RAMOS et al., 2006). Farias et al. (2008), Azevedo et al. (2009) and Silva et al. (2011), indicate the possibility of using dehydrated cashew apple meal as an alternative food in the feeding of poultry, pigs and sheep, however, the potential use of this ingredient as a source of fiber, particularly as a substitute for alfalfa hay in food for rabbits in the growth phase can also be noted.

Based on the considerations above, this study aimed to determine the chemical composition, the digestibility of nutrients and energy of the dehydrated cashew apple meal, as well as to evaluate the inclusion of increasing levels of this ingredient in food for growing rabbits in terms of performance, carcass characteristics and economic evaluation.

\section{Material and Methods}

The experiment followed the protocols approved by the Ethics Committee on Animal Research (CEPA 54/2013) of the Federal University of Ceará. They are in accordance with ethical principles in animal experimentation, adopted by the Brazilian College of Animal Experimentation.

The primary material to obtain the dehydrated cashew apple meal used in this study came from the Industry Ali Polpas, located in the city of Aquiraz- 
Ceará, in Brazil, and was obtained after the extraction of the pseudofruit's juice in continuous presses, called expeller, for the manufacturing of cashew pulp, which is composed by the skin and pulp from the remaining of the apple. The dehydration process used consisted in exposing the residue of the pseudo fruit cashew to the sun, under plastic canvas on cemented area for four days, flipping them in order to guarantee a harmonized drying and to prevent the fermenting of the material. After drying the residue from the pseudo fruit cashew, the grinding in a hammer mill and the sifting were followed to facilitate the ingredient's incorporation into feed.

A metabolism trial was conducted, in the experimental Rabbit Breeding Sector of the Federal
University of Ceará, in Fortaleza - Ceará - Brazil, to determine the chemical composition, the nutrient digestibility coefficients and the digestible energy value of the dehydrated cashew apple meal, being used 24 mixed breed rabbits (White New Zealand $\mathrm{x}$ California), 12 males and 12 females, with 55 days of age and initial average weight of $1203 \pm 57 \mathrm{~g}$, distributed in a completely randomized design, with two treatments and 12 repetitions, being one with reference feed (Table 1) prepared in accordance with the nutritional recommendations of De blas and Wiseman (2010) for rabbits in the growth phase, and the other with a test feed, in which the ingredient evaluated replaced the reference feed in a percentage of $30 \%$, based on the natural matter.

Table 1. Centesimal and chemical composition of the control diet.

\begin{tabular}{lc}
\hline Ingredient & $(\%)$ \\
\hline Ground corn & 21.65 \\
Alfalfa hay & 22.08 \\
Wheat bran & 24.00 \\
Tifton hay & 17.00 \\
Soybean meal & 11.59 \\
Soybean oil & 1.13 \\
Calcitic limestone & 0.98 \\
Dicalcium phosphate & 0.34 \\
Mineral/vitamin supplement ${ }^{2}$ & 0.30 \\
Sodium Chloride & 0.50 \\
L-lysine HCl & 0.26 \\
DL-methionine & 0.17 \\
\hline Total & 100.00 \\
\hline Calculated composition ${ }^{1}$ & \\
\hline Digestible energy (kcal/kg) & 2500 \\
Crude protein (\%) & 16.00 \\
Acid detergent fiber (\%) & 16.50 \\
Neutral detergent fiber $(\%)$ & 29.79 \\
Starch (\%) & 21.96 \\
Calcium (\%) & 0.7993 \\
Total phosphorus (\%) & 0.5006
\end{tabular}


continuation

Methionine + cystine $(\%)$

Total lysine $(\%)$

${ }^{1}$ Based on the chemical composition values of the raw materials from the diets. ${ }^{2}$ Vitamin-mineral supplement, composition per kilogram of feed: vit. A: $15 \mathrm{IU}$, vit. D3: $0.015 \mathrm{IU}$, vit. E: 30mg, vit. K3: 3mg, vit. B1: 3mg, vit. B2: 9mg, vit. B6: $3.75 \mathrm{mg}$, vit. B12: $150 \mathrm{mcg}$, pantothenic acid: $30 \mathrm{mg}$, folic acid: $1,500 \mathrm{mcg}$, nicotinic acid: $60 \mathrm{mg}$, choline: $7.81 \mathrm{mg}$, sulfur: $120.30 \mathrm{mg}$, manganese: $30 \mathrm{mg}$, copper: $9 \mathrm{mg}$, iron: $0.09 \mathrm{mg}$, zinc: $75 \mathrm{mg}$, cobalt: $1.5 \mathrm{mg}$, iodine: $0.45 \mathrm{mg}$, selenium: $0.15 \mathrm{mg}$.

The animals were single-housed in metabolism cages, provided with automatic water nipple drinkers and semi-automatic feeders made of galvanized sheets. At the bottom, the cages had nylon mesh to collect the feces. The cages were installed in brick shed with a ceiling height of three meters, covered by a clay tile roof and screen sidewalls. The trial lasted eleven days, of which seven were destined for the adaptation of the animals to the facilities and the diets and four days for the fecal collection.

The animals received water and feed freely throughout the experimental period, being the ration feed provided twice a day. The feces collected daily, in the morning, were placed in plastic bags and then taken to the freezer at $-18{ }^{\circ} \mathrm{C}$. At the end of the collection period, they were homogenized and placed in a forced ventilation oven at $55{ }^{\circ} \mathrm{C}$ for a period of 72 hours, for pre-drying, to be weighed and ground afterwards, removing samples of the pre-dried material for analysis.

The analysis of the ingredients' DM, MM, CP, EE, NDF and ADF from the feed and feces were performed according to the methods described by AOAC (2005), and the analysis of the energy was conducted in a calorimetric adiabatic bomb PARR Model 1241EA.

To determine the digestible protein (DP) contents and digestible dry matter (DDM), the DCAM, the equations of Matterson et al. (1965) were used and for the GE the equation of Villamide (1996).

For the performance trial, 120 rabbits were used, emerged by cross-breeding females of the breed California X males of the breed White New Zealand, with 45 days of age and average weight of1143 $\pm 153 \mathrm{~g}$, being 60 males and 60 females. The rabbits were housed, in same-sex pairs, in galvanized wire cages, with dimensions of $80 \mathrm{~cm}$ x $60 \mathrm{~cm} \mathrm{x} 45 \mathrm{~cm}$ (length, width and height), with automatic water nipple drinkers and semi-automatic feeder made of galvanized sheets, installed in an open brick shed, provided with side protection screens, with 7.60 meters of width, ceiling height of 3 meters and covered with a clay tile roof.

The animals were weaned at 35 days of age and housed in collective cages, receiving water and commercial feed at will up to 45 days of age, when they were individually weighed, identified and distributed in experimental cages according to the weight so that all treatments maintained similar initial average weight.

The experimental design was completely randomized, with six treatments and ten repetitions, being the experimental unit composed of two animals. The treatments consisted in a control feed, based on corn, alfalfa hay, soybean bran and wheat bran, and the rest, with the inclusion of dehydrated cashew apple meal at levels of 10, 20, 30, 40 and $50 \%$.

The experimental feeds (Table 2) were formulated to keep the same nutritional level in accordance with the requirements for growing rabbits (DE BLAS; WISEMAN, 2010). The values of chemical composition and digestible energy of the dehydrated cashew apple meal determined in the metabolism trial were considered. 
The feeds were pelletized in a pelletizing machine of the brand Silver Model CZ 350, steam, with aconditioner's average temperature of $70^{\circ} \mathrm{C}$ and capacity for $350 \mathrm{~kg}$ of feed per hour. A die with a diameter of $4.0 \mathrm{~mm}$ and pellet cutting with a 10 $\mathrm{mm}$ length was used.

Throughout the experimental period the animals received food and water freely.
For the measurement of the performance variables the weighing of the animals was conducted in the beginning and at the end of the trial period, as well as the remains of the experimental feeds, which were collected in plastic bags and quantified daily for correction of consumption. The data of average daily weight gain and averaged daily feed consumption were obtained by the difference between the results of the weighing and from this data the feed conversion was calculated.

Table 2. Composition and nutritional levels of the experimental diets for growing rabbits.

\begin{tabular}{|c|c|c|c|c|c|c|}
\hline \multirow{2}{*}{ Ingredient $(\mathrm{kg})$} & \multicolumn{6}{|c|}{${ }^{1}$ DCAM inclusion level (\%) } \\
\hline & 0 & 10 & 20 & 30 & 40 & 50 \\
\hline Alfalfa hay & 44.24 & 34.88 & 25.51 & 16.15 & 6.79 & 0.00 \\
\hline Wheat bran & 24.00 & 24.00 & 24.00 & 24.00 & 24.00 & 15.58 \\
\hline Ground corn & 22.60 & 21.57 & 20.55 & 19.52 & 18.49 & 22.61 \\
\hline Soybean meal (45\%) & 4.82 & 5.26 & 5.70 & 6.14 & 6.58 & 7.83 \\
\hline Dehydrated cashew apple meal & 0.00 & 10.00 & 20.00 & 30.00 & 40.00 & 50.00 \\
\hline Soybean oil & 1.77 & 1.47 & 1.16 & 0.86 & 0.55 & 0.00 \\
\hline Calcitic limestone & 0.69 & 0.81 & 0.93 & 1.05 & 1.17 & 1.06 \\
\hline Dicalcium phosphate & 0.32 & 0.47 & 0.62 & 0.77 & 0.92 & 1.37 \\
\hline Mineral/vitamin supplement ${ }^{1}$ & 0.30 & 0.30 & 0.30 & 0.30 & 0.30 & 0.30 \\
\hline Sodium Chloride & 0.51 & 0.51 & 0.51 & 0.51 & 0.51 & 0.51 \\
\hline L-lysineHCl & 0.50 & 0.48 & 0.47 & 0.46 & 0.45 & 0.48 \\
\hline DL-methionine & 0.25 & 0.25 & 0.25 & 0.25 & 0.24 & 0.26 \\
\hline TOTAL & 100.00 & 100.00 & 100.00 & 100.00 & 100.00 & 100.00 \\
\hline Price/kg of diet (U\$) & 0.46 & 0.43 & 0.41 & 0.39 & 0.38 & 0.37 \\
\hline \multicolumn{7}{|c|}{ Calculated nutritional and energy composition } \\
\hline Digestible energy $(\mathrm{kcal} / \mathrm{kg})$ & 2.500 & 2.500 & 2.500 & 2.500 & 2.508 & 2.500 \\
\hline Crude protein $(\%)$ & 16.00 & 16.00 & 16.00 & 16.00 & 16.00 & 16.00 \\
\hline Dry matter $(\%)$ & 89.1 & 89.8 & 89.6 & 90.4 & 90.8 & 91.2 \\
\hline Acid detergent fiber $(\%)$ & 16.50 & 16.50 & 16.50 & 16.50 & 16.50 & 16.52 \\
\hline Neutral detergent fiber (\%) & 29.77 & 32.43 & 35.07 & 34.72 & 40.37 & 43.22 \\
\hline Starch $(\%)$ & 21.82 & 20.77 & 20.18 & 19.60 & 19.02 & 17.59 \\
\hline Calcium (\%) & 0.80 & 0.80 & 0.80 & 0.80 & 0.80 & 0.80 \\
\hline Total phosphorus (\%) & 0.50 & 0.50 & 0.50 & 0.50 & 0.50 & 0.50 \\
\hline Sodium (\%) & 0.22 & 0.22 & 0.22 & 0.22 & 0.22 & 0.22 \\
\hline Total lysine (\%) & 0.73 & 0.73 & 0.73 & 0.73 & 0.73 & 0.73 \\
\hline Total methionine (\%) & 0.36 & 0.37 & 0.37 & 0.37 & 0.37 & 0.38 \\
\hline
\end{tabular}


continuation

\begin{tabular}{lllllll} 
Total methionine + cystine $(\%)$ & 0.52 & 0.52 & 0.52 & 0.52 & 0.52 & 0.52 \\
Total threonine $(\%)$ & 0.27 & 0.28 & 0.28 & 0.29 & 0.29 & 0.29 \\
Total tryptophan $(\%)$ & 0.09 & 0.09 & 0.09 & 0.09 & 0.09 & 0.10 \\
\hline
\end{tabular}

${ }^{1}$ DCAM, dehydrated cashew apple meal, Composition per kg of feed: vit. A: 15 IU, vit. D3: 0.015 IU, vit. E: 30mg, vit. K3: 3mg, vit. B1: 3mg, vit. B2: 9mg, vit. B6: 3.75mg, vit. B12: $150 \mathrm{mcg}$, pantothenic acid: $30 \mathrm{mg}$, folic acid: $1,500 \mathrm{mcg}$, nicotinic acid: $60 \mathrm{mg}$, choline: $7.81 \mathrm{mg}$, sulfur: $120.30 \mathrm{mg}$, manganese: $30 \mathrm{mg}$, copper: $9 \mathrm{mg}$, iron: $0.09 \mathrm{mg}$, zinc: $75 \mathrm{mg}$, cobalt: $1.5 \mathrm{mg}$, iodine: $0.45 \mathrm{mg}$, selenium: $0.15 \mathrm{mg}$.

For the evaluation of carcass characteristics, at 90 days of age, all the rabbits were sent to slaughter. Initially the rabbits were weighed and subjected to fasting for 12 hours and, after this period, were weighed again to obtain the weight at slaughter which was carried out with stunning and bleeding by cutting the jugular vein. Subsequently, the skin, legs, tail and head were removed.

The eviscerated carcass, liver, kidneys, heart and abdominal fat were weighed to calculate the carcass yield and proportions of the parts.

The carcass yield (\%) was obtained by the ratio of the weight of the eviscerated hot carcass and the rabbit's weight at slaughter and the final result was multiplied by 100 . The relative weight data (\%) of liver, kidneys and heart were obtained by the relation between the weight of the evaluated part and the live weight and percentage of abdominal fat was obtained by the ratio between the weight of the evaluated part and the hot carcass weight.

The hind legs were removed, weighed and dissected according to the method described by Blasco and Ouhayoun (1996) and the right led was used to obtain the relationship meat/bone according to the formula $\mathrm{RC} / \mathrm{O}=$, in which $\mathrm{RC} / \mathrm{O}$ is the ratio meat/bone, Pca is the weight of the meat $(\mathrm{g})$ and PO is the weight of bones $(\mathrm{g})$, according to Rao et al. (1978).

To verify the economic viability of including the dehydrated cashew apple meal in the feeds, it was initially determined the cost of the feed per kilogram of live weight gain (Yi), according to Bellaver et al. (1985): considering $\mathrm{Yi}=(\mathrm{Qi} \times \mathrm{Pi}) / \mathrm{Gi}$, where: $\mathrm{Yi}$ $=$ cost of the feed per kilogram of live weight gain in the $\mathrm{i}$-th treatment; $\mathrm{Pi}=$ price per kilogram of the feed used in the i-th treatment; Qi = the quantity of feed consumed in the $\mathrm{i}$-th treatment and $\mathrm{Gi}=$ weight gain of the $i$-th treatment.

Then the Economic Efficiency Index (EEI) and the Cost Index (CI) were calculated, proposed by Fialho et al. (1992): EEI $=(\mathrm{MCei} / \mathrm{S}, \mathrm{TeI}) \times 100$ and $\mathrm{CI}=(\mathrm{S}, \mathrm{TeI} / \mathrm{MCei}) \times 100$, where $\mathrm{MCei}=$ lower cost of the feed per $\mathrm{kg}$ of gain observed between treatments and $\mathrm{STei}=$ cost of considered $\mathrm{i}$ treatment.

In the calculation, the price of the ingredients was considered according to the values practiced at the time of the experiment in the city of Fortaleza, being the amounts of $\$ 0.21 ; \$ 0.61 ; \$ 0.46 ; \$ 0.26$; \$ $0.04 ; \$ 0.90 ; \$ 0.06 ; \$ 0.96 ; \$ 3.53 ; \$ 0.19 ; \$$ 4.56 and $\$ 2.74$ for the kilogram of corn, alfalfa hay, soybean bran, wheat bran, DCAM, soybean oil, limestone, dicalcium phosphate, mineral and vitamin supplement, common salt, L-lysine $\mathrm{HCl}$ and DL-methionine, respectively.

The statistical analysis was performed using a statistical software Statistical Analysis System (2001), and the statistical model utilized for the variance analysis was Yijk $=\mu+\mathrm{Li}+\mathrm{Sj}+\mathrm{LSij}+$ eijk, where $\mu=$ overall mean; $\mathrm{Li}=$ effect of the level of inclusion of the dehydrated cashew apple meal ( $\mathrm{i}$ $=0,10,20,30,40$ and $50 \%), \mathrm{Sj}$ is the effect of sex $(j=$ male and female), LSij $=$ effect of the level of inclusion $\mathrm{i}$ on sex $\mathrm{j}$; and eijk $=$ effect of the error. 
The degrees of freedom referring to the levels of inclusion of dehydrated cashew apple meal, excluding the reference feed (level zero of inclusion of DCAM) were broken down into polynomials, to establish the curve that best described the behavior of the data. To compare the results obtained with each of the inclusion levels in relation to the feed without the ingredient (0\%), Dunnett's 5\% probability test was used.

\section{Results and Discussion}

With the evaluation of the chemical composition of dehydrated cashew apple meal (Table 3), it was verified that the values found are similar to the results obtained by Ramos et al. (2006), Azevedo et al. (2009) and Leite et al. (2013), with small variations that can be attributed to the fact that the composition of by-products can be influenced by the type and time spent on the processing applied and, in the case of food of plant origin, factors such as soil, climate, genetic variability and storage conditions of the food can influence its composition (FREITAS et al., 2005; BRUMANO et al, 2006; GOMES et al, 2007; NERY et al., 2007).

The coefficients of apparent digestibility of dry matter, crude energy and crude protein, and experimental ingredients are in Table 4. The value of $2,119 \mathrm{kcal}$ of the digestible energy/ $\mathrm{kg}$ obtained for the dehydrated cashew apple meal can be considered reasonable, due to its high content of crude fiber. It is also observed that this ingredient showed reduced DM digestibility coefficient, which can be due to the ADF content in the diet and to a greater amount of fiber, which tends to reduce the digestibility, since the rabbit's cecum is located after the absorptive system, unlike what occurs in ruminant animals. Therefore, not only the quantity but also the quality of the fiber incorporated into the diet, associated with starch content, can cause changes in the digestive physiology in this species. According to Faria et al. (2008), the fiber also increases the digestive transit speed, making the enzymatic action in the small intestine difficult, which may have influenced the reduced value found for the DM digestibility coefficient. On the other hand, the value of the coefficient of the apparent digestibility for crude protein of DCAM (30.03\%) was low, what indicates that the rabbits cannot take advantage, with good efficiency, of the nitrogen fraction of the DCAM, which can be explained by the presence of tannins in this by-product that can reduce the digestibility of the protein, carbohydrates and minerals, besides decreasing the activity of digestive enzymes, causing damage to the mucus of the digestive system or producing systemic toxic effects (SREERAMA et al., 2010). According to Ramos et al. (2006), the dehydrated cashew apple meal has high tannin content ranging from 1.04 to $1.80 \%$.

Table 3. Chemical composition and energy values of the dehydrated cashew apple meal (dry matter basis) ${ }^{1}$.

\begin{tabular}{lc}
\hline Nutrients and energy & CADM $^{2}$ \\
\hline Dry matter (\%) & 87.85 \\
Gross energy (kcal/kg) & 4360.41 \\
Crude protein (\%) & 15.85 \\
Ether extract (\%) & 4.44 \\
ADF (\%) & 26.79 \\
NDF (\%) & 62.64 \\
Mineral matter (\%) & 3.98 \\
\hline
\end{tabular}

${ }^{1}$ Analyses performed at the Laboratory of Animal Nutrition (LANA) Of the Department of Animal Science of UFC. DCAM ${ }^{2}$, dehydrated cashew apple meal. ADF, acid detergent fiber (\%); NDF, neutral detergent fiber (\%). 
Table 4. Digestibility coefficients, digestible nutrients and digestible energy of the dehydrated cashew apple meal for growing rabbits.

\begin{tabular}{lcc}
\hline Nutrients and energy & Digestibility coefficient (\%) & Digestible nutrients and digestible energy \\
\hline Dry matter (\%) & 67.79 & $59.55 \%$ \\
Crude protein (\%) & 30.03 & $4.76 \%$ \\
Energy (kcal $/ \mathrm{kg})$ & 48.61 & $2,119.66 \mathrm{kcal} / \mathrm{kg}$ \\
\hline
\end{tabular}

According to the results (Table 5), there was no significant interaction $(\mathrm{P}>0.05)$ between the levels of inclusion of the DCAM and sex on the performance variables assessed.

The inclusion of DCAM in the feeds did not influence $(\mathrm{P}>0.05)$ the final live weight at 90 days of age and the average daily feed consumption, but promoted a quadratic effect on weight gain $(\mathrm{Y}=$ $20.465+0.2987 \mathrm{X}-0.0059 \mathrm{X}^{2} ; \mathrm{R}^{2}=0.86$ ), indicating that, at this stage, the use of up to $25.31 \%$ inclusion levels of DCAM should not be recommended, because it decreases performance and worsens feed conversion $\left(\mathrm{Y}=3.49+0.011 \mathrm{X} ; \mathrm{R}^{2}=0.88\right)$, since for each $1 \%$ of inclusion of DCAM in feeds, there is an increase in the order of 0.011 in the feed conversion.

Table 5. Performance of rabbits fed diets containing different levels of dehydrated cashew apple meal.

\begin{tabular}{|c|c|c|c|c|}
\hline \multirow{2}{*}{$\begin{array}{l}\text { Inclusion } \\
\text { level (\%) }\end{array}$} & \multicolumn{4}{|c|}{ Parameter } \\
\hline & Final weight $(\mathrm{kg})$ & Feed intake (g/rabbit/day) & Weight gain ( $\mathrm{g} / \mathrm{rabbit} /$ day) & Feed conversion $(\mathrm{g} / \mathrm{g})$ \\
\hline 0 & 2.31 & 75.93 & 22.58 & 3.36 \\
\hline 10 & 2.30 & 84.55 & 23.16 & 3.65 \\
\hline 20 & 2.31 & 84.57 & 23.57 & 3.58 \\
\hline 30 & 2.31 & $91.04 *$ & 23.91 & 3.81 \\
\hline 40 & 2.32 & $93.01 *$ & 23.88 & 3.89 \\
\hline 50 & 2.12 & 83.24 & 20.30 & 4.11 \\
\hline \multicolumn{5}{|l|}{ Sex } \\
\hline Male & 2.27 & 86.78 & 22.30 & $3.89^{\mathrm{a}}$ \\
\hline Female & 2.28 & 83.80 & 23.44 & $3.58^{\mathrm{b}}$ \\
\hline Mean & 2.28 & 85.26 & 22.88 & 3.73 \\
\hline $\mathrm{CV}^{1}(\%)$ & 8.40 & 11.92 & 11.87 & 15.18 \\
\hline ANOVA $^{2}$ & & & P-value & \\
\hline Level & 0.1666 & 0.0097 & 0.0430 & 0.2050 \\
\hline Sex & 0.8485 & 0.2382 & 0.1321 & 0.0198 \\
\hline Level $\times$ Sex & 0.8898 & 0.9380 & 0.7847 & 0.8596 \\
\hline \multicolumn{5}{|l|}{ Regression } \\
\hline Linear & 0.0726 & 0.6316 & 0.0265 & 0.0311 \\
\hline Quadratic & 0.0597 & 0.0658 & 0.0030 & 0.4957 \\
\hline
\end{tabular}

$\mathrm{CV}$, coefficient of variation; ANOVA.analysis of variance. ${ }^{\mathrm{a} . \mathrm{b}}$ means followed by different letters in the column $\operatorname{differ}(\mathrm{P}<0.05)$ by the F test.* Differs statistically compared with the control treatment by Dunnett's test $(\mathrm{P}<0.05)$. 
During the experiment it was averaged environment temperature of $28.80^{\circ} \mathrm{C}, 36.45^{\circ} \mathrm{C}$ and $25.32{ }^{\circ} \mathrm{C}$ the maximum and minimum temperatures, respectively, with average relative humidity in the shed during the trial period of $62.13 \%$. The environment's temperature is a factor that influences significantly the productivity of the rabbits, since these animals are warm-blooded and need to maintain a body temperature within a narrow range (15 and $25^{\circ} \mathrm{C}$ ) in order to develop and reproduce properly. In tropical climate countries, such as Brazil, the heat exposure is more problematic and its primary consequence is the reduction of food consumption (BANI et al., 2005) to decrease the production of metabolic heat and maintain homeothermia. Thus, the energy and nutrient consumption is dimished to levels that can compromise the productivity. Besides the reduction of food consumption, the heat exposure promotes direct effect over the rabbit's metabolism, what generates physiological stress, damages the immune function and reduces the rabbit's performance during the growth period (BANI et al., 2005). In this trial, the rabbits probably spent more energy to thermoregulate themselves, consequently, the energetic use for growth was lower and this would explain the decrease of weight gain without variations on feed intake.

On the other hand, when comparing the results obtained with the different inclusion levels of
DCAM in relation to those obtained with the feed without the ingredient, it was observed that rabbits fed with levels of DCAM from 30\% consumed a larger amount of feed $(\mathrm{P}<0.05)$, possibly due to the fiber quality, since the biggest lignification of cell wall constituents stimulates the motility increase in the rabbits' cecum-colon region, leading to a greater rate of passage and more frequent consumption of food (ARRUDA et al., 2003a). Moreover, the feed conversion and weight gain did not differ $(\mathrm{P}>0.05)$ for the results of rabbits fed with the control feed, possibly due to the maintenance of growth speed or weight gain at similar rates between the dietary treatments, reflecting the stability of feed conversion and the maintenance of nutrient use efficiency by regulating the consumption (DE BLAS et al., 1986; ARRUDA et al., 2003b).

Reggarding the effect of sex on performance, it was observed that females showed better feed conversion $(\mathrm{P}<0.05)$ than the males, which can be understood by the shortest maturation of females, which tend to present a better food conversion rate and greater accumulation of abdominal fat when compared to males in the growth phase.

For carcass characteristics (Table 6), it was observed that the inclusion of dehydrated cashew apple meal in the feeds, influenced significantly ( $P$ $<0.05$ ) the carcass yield, the ratio meat/bone and the proportion of the kidneys in the carcass.

Table 6. Carcass characteristics of growing rabbits fed diets containing increasing levels of dehydrated cashew apple meal.

\begin{tabular}{ccccccc}
\hline \multirow{2}{*}{ Inclusion level (\%) } & \multicolumn{5}{c}{ Parameter (\%) } \\
\cline { 2 - 6 } & Carcass yield & M/B & Liver $^{1}$ & Heart & Kidneys & Abdominal fat \\
\hline 0 & 54.48 & 7.49 & 2.48 & 0.20 & 0.57 & 2.82 \\
10 & 55.10 & 7.68 & 2.66 & 0.18 & 0.53 & 2.46 \\
20 & 54.09 & 7.20 & 2.69 & 0.19 & 0.60 & 2.40 \\
30 & 54.16 & 7.96 & 2.42 & 0.19 & 0.56 & 2.60 \\
40 & 54.58 & 7.46 & 2.31 & 0.19 & 0.62 & 2.45 \\
50 & $52.19^{*}$ & $6.79^{*}$ & 2.53 & 0.19 & 0.62 & 2.57 \\
\hline
\end{tabular}

continue 
continuation

\begin{tabular}{ccccccc}
\hline Sex & \multicolumn{7}{c}{} & \\
\hline Male & 54.00 & 7.41 & 2.56 & 0.19 & 0.58 & $2.27^{\mathrm{b}}$ \\
Female & 54.18 & 7.44 & 2.48 & 0.19 & 0.59 & $2.77^{\mathrm{a}}$ \\
\hline Mean & 54.09 & 7.43 & 2.52 & 0.19 & 0.58 & 2.52 \\
\hline CV (\%) & 2.51 & 7.08 & 15.19 & 8.33 & 8.45 & 21.55 \\
\hline ANOVA & & P-value & & \\
\hline Level & 0.0005 & 0.0003 & 0.2677 & 0.3099 & 0.0021 & 0.2716 \\
Sex & 0.6331 & 0.8397 & 0.4471 & 0.2415 & 0.4370 & 0.0009 \\
Level $\times$ Sex & 0.7768 & 0.6353 & 0.9195 & 0.4881 & 0.5612 & 0.8926 \\
\hline Regression & & & & & \\
\hline Linear & 0.0007 & 0.0197 & 0.1201 & 0.0552 & 0.0022 & 0.8670 \\
Quadratic & 0.1941 & 0.0287 & 0.2681 & 0.9982 & 0.6984 & 0.7680 \\
\hline
\end{tabular}

$\mathrm{CV}$. coefficient of variation; ANOVA. analysis of variance; M/B. meat/bone ratio.1Ratio between the organ weight and the rabbit live weight after feed deprivation ${ }^{\text {a.b }}$ means followed by different letters in the column differ $(\mathrm{P}<0.05)$ by the $\mathrm{F}$ test.* Differs statistically compared with the control treatment by Dunnett's test $(\mathrm{P}<0.05)$.

According to the regression analysis, excluding the control treatment, the carcass yield $(\mathrm{Y}=55.63$ $\left.-0.053 \mathrm{X} ; \mathrm{R}^{2}=0.59\right)$, decreased linearly with the addition of DCAM in feed. This result can be assumed due to the higher relative weight of the digestive system because of the greater occupation of the gastrointestinal tract as a way to compensate the lower energy intake, corroborating with the results obtained by Arruda et al. (2003b), that found elevated feed conversion and reduced carcass yield with more fibrous feed, suggesting the effect on the digestion's traffic speed.

The ratio meat / bone $(\mathrm{Y}=7.060+0.05423 \mathrm{X}$ $\left.-0.0011 X 2 ; R^{2}=0.53\right)$ showed a quadratic effect, with less meat deposition in the carcass due to the increase of DCAM levels, being these values proportional to the lower carcass yield, which reflect in a lower deposition of muscle in the carcass of these animals. The maximum estimated value of this variable occurred at the level of $24.65 \%$ of inclusion, stating that, until that level, the rabbits present higher percentage value of meat in carcass, decreasing from there on, probably due to the increasing fiber content, possibly for interfering with the absorption of nutrients.

Comparing dehydrated cashew apple meal inclusion levels to the treatment without the ingredient, it was observed that only for the level of inclusion of $50 \%$ of DCAM in diets there was a negative influence on carcass yield and meat deposition in the carcass of rabbits, decreasing the ratio meat/bone, which provides a reasonably good prediction of the rate of meat contained in the carcass, suggesting that the muscle protein deposit is lower when compared to the control treatment, because there is a reduction in the production of meat. The value of the ratio meat/bone ratio in the control treatment was lower than the one obtained by Oliveira and Lui (2006), when also working with growing rabbits, who acquired a meat/bone ratio of 7.92 .

For the relative weight of kidneys, on the other hand, there was a linear increase $(\mathrm{Y}=0.526+$ $\left.0.002 \mathrm{X} ; \mathrm{R}^{2}=0.63\right)$ with the inclusion of DCAM in feed. According to Ngoshe et al. (2013), it is a common practice in experiments with alternative food using the weights of some internal organs, such 
as liver and kidney, as indicators of toxicity. Bone (1979) reported that, if there is any toxic element in the feed, abnormalities would be observed in the weights of these organs and that this increase would be due to the increased metabolic rate of the organs in an attempt to reduce these toxic elements or antinutritional factors for non-toxic metabolites.

According to Ramos et al. (2006), the pomace of the pseudo fruit cashew presents tannin levels ranging from 1.04 to $1.80 \%$, which could result in increased kidneys, besides reducing the digestibility of protein, carbohydrates and minerals and decrease the activity of digestive enzymes, which may cause damage to the mucus of the digestive system or have systemic toxic effects (SREERAMA et al., 2010).

Inherent effects in the sexual dimorphism on variables of carcass characteristics showed that females had a higher percentage of abdominal fat deposition compared to males. These data are in agreement with Ortiz Hernandez and Rubio Lozano (2001), who stated that the abdominal fat deposits tend to be higher in female rabbits.

Table 7 shows the results of the economic analysis. Excluding the control treatment, it was noted that, with the inclusion of dehydrated cashew apple meal in feed for the growth phase, there was a linear reduction in the cost of feed per $\mathrm{kg}$ of weight gain $(Y=5,069-0,052 X ; R 2=0.99)$, linear increase in the economic efficiency ratio $(\mathrm{Y}=43.46$ $+0,109 \mathrm{X} ; \mathrm{R} 2=0.99$ ) and linear reduction in the cost index $(Y=199.22$ - 0,0299X; R2 = 0.99).

The inclusion levels of dehydrated cashew apple meal in feed for rabbits starting at $20 \%$, resulted in lower cost with feeding and better EEI and CI for the animals fed the control feed, which showed a higher cost per kilogram produced and, consequently, the worst rates of economic efficiency and cost for rabbits between 45 to 90 days old.

The results obtained for the economic viability of the inclusion of dehydrated cashew apple meal in rabbit feed are similar to those reported by Farias et al. (2008), who evaluated the inclusion of dehydrated cashew apple meal in feed for pigs and found a linear reduction in the cost of feeding, linear increase in the economic efficiency ratio and linear reduction in the cost index as the dehydrated cashew apple meal was included in the feeds.

Table 7. Economic evaluation of the inclusion of dehydrated cashew apple meal in the feeding of growing rabbits.

\begin{tabular}{cccc}
\hline \multirow{2}{*}{ Inclusion level (\%) } & \multicolumn{3}{c}{ Evaluated parameter } \\
\cline { 2 - 4 } & Cost with feeding (R $\$$ kg of gain) & Economic efficiency index (\%) & Cost index (\%) \\
\hline 0 & 4.97 & 53.00 & 195.00 \\
10 & 4.62 & 56.00 & 182.00 \\
20 & $3.96^{*}$ & $66.00^{*}$ & $156.00^{*}$ \\
30 & $3.51^{*}$ & $74.00^{*}$ & $138.00^{*}$ \\
40 & $2.93^{*}$ & $87.00^{*}$ & $116.00^{*}$ \\
50 & $2.54^{*}$ & $100.00^{*}$ & $100.00^{*}$ \\
\hline Sex & & & 150.00 \\
Male & $3.98^{\mathrm{a}}$ & 72.00 & 147.00 \\
\hline Female & $3.56^{\mathrm{b}}$ & 73.00 & 148.50 \\
\hline Mean & 3.77 & 72.50 & 17.36 \\
\hline CV $(\%)$ & 17.70 & 14.52 &
\end{tabular}

continue 
continuation

\begin{tabular}{cccc}
\hline ANOVA & & P-value & \\
\hline Level & 0.0001 & 0.0001 & 0.0001 \\
Sex & 0.0334 & 0.9840 & 0.7410 \\
Level $\times$ Sex & 0.8810 & 0.6667 & 0.9404 \\
\hline Regression & & & \\
Linear & 0.0001 & 0.0001 & 0.0001 \\
Quadratic & 0.5078 & 0.3281 & 0.4666 \\
\hline
\end{tabular}

CV. coefficient of variation; ANOVA. analysis of variance. ${ }^{a . b}$ means followed by different letters in the column differ $(\mathrm{P}<0.05)$ by the F test.* Differs statistically compared with the control treatment by Dunnett's test $(\mathrm{P}<0.05)$.

It is noteworthy that although the level of inclusion of $50 \%$ of DCAM in diets has better results in economic indexes, all the evaluated feeds containing the ingredient showed to be economically more efficient than the control diet, which is related to the fact that the cost of the by-product concerned is low, when compared to alfalfa hay.

Considering that, during the growth period, the weight gain and carcass characteristics of rabbits fed with an approximate level of $25 \%$ of inclusion of DCAM were similar to those of animals fed with the control feed $(0 \%)$ and the rise of the inclusion of this ingredient in feeds improved the economic viability, it can be inferred that it is possible to include up to $25 \%$ of DCAM in rabbit feed destined for slaughter without changes in performance, corroborating with the values indicated by Fanimo et al. (2003), who recommended levels of 20 to $30 \%$ of DCAM in feed for rabbits aged from 45 to 90 days.

\section{Conclusions}

The digestibility coefficients of dry matter, crude protein and gross energy of dehydrated cashew apple meal found were, respectively, 67.79; 30.03 and $48.61 \%$. The digestible dry matter, digestible protein and digestible energy, based on dry matter, were, respectively, 59.55\%; $4.76 \%$ and $2,119.66$ $\mathrm{kcal} / \mathrm{kg}$.
Performance data indicate that the pseudo fruit cashew meal can be added up to the level of $25 \%$ in growing rabbits feed and that the inclusion of dehydrated cashew apple meal improves the economic viability of the production.

\section{References}

ARRUDA, A. M. V.; LOPES, D. C.; FERREIRA, W. M.; ROSTAGNO, H. S.; QUEIROZ, A. C.; PEREIRA, E. S.; FERREIRA, A. S.; SILVA, J. F. Desempenho e características de carcaça de coelhos alimentados com rações contendo diferentes níveis de amido e fontes de fibra. Revista Brasileira de Zootecnia, Viçosa, MG, v. 32, n. 6, p. 1311-1320, 2003b.

ARRUDA, A. M. V.; PEREIRA, E. S.; MIZUBUTI, I. Y.; SILVA, L. D. F. Importância da fibra na nutrição de coelhos. Semina: Ciências Agrárias, Londrina, v. 24, n. 1, p. 181-190, 2003a.

ASSOCIATION OF OFFICIAL ANALYTICAL CHEMISTS - AOAC. Official methods of analysis of the Association Analytical Chemists International. $18^{\text {th }}$ ed. Gaithersburg: MD U.S.A Official Methods, 2005.

AZEVEDO, M. M. R.; VASCONCELOS, V. R.; PIMENTEL, J. C. M.; PINTO, B. I. S.; ARAÚJO NETO, J. C.; CARVAlho, A. A. Dinâmica de fermentação ruminal in vitro do pseudofruto de cinco clones de cajueiro. Revista Brasileira de Zootecnia, Viçosa, MG, v. 38, n. 4, p. 752-759, 2009.

BANI, P.; PICCIOLI, F.; CAPPELLI, A. Variations of some blood parameters in rabbit reared under different environmental conditions. Italian Journal of Animal Science, Bologna, v. 4, n. 2, p. 535-537, 2005. 
BELlAVER, C.; FIALHO, E. T.; PROTAS, J. F.; GOMES, P. C. Radícula de malte na alimentação de suínos em crescimento e terminação. Pesquisa Agropecuária Brasileira, Brasília, v. 20, n. 8, p. 969-974, 1985.

BLASCO, A.; OUHAYOUN, J. Harmonization of criteria and terminology in rabbit meat research. Revised proposal. World Rabbit Science, Valência, v. 4, n. 2, p. 93-99, 1996.

BONE, F. J. Anatomy and phisiology of farm animals. $2^{\text {th }}$ ed. Virgínia: Reston Publishing Comp, Inc., 1979. 560 p.

BRUMANO, G.; GOMES, P. C.; ALBINO, L. F. T.; ROSTAGnO, H. S.; Generoso, R. A. R.; SCHMIDT, M. Composição química e valores de energia metabolizável de alimentos proteicos determinados com frangos de corte em diferentes idades. Revista Brasileira de Zootecnia, Viçosa, MG, v. 35, n. 6, p. 2297-2302, 2006.

DE BLAS, C.; WISEMAN, J. The nutrition of the rabbit. $2^{\text {th }}$ ed. Cambridge: CAB International, 2010. 325 p.

DE BLAS, J. C.; SANTOMÁ, G.; CARABAÑO, R. Fiber and starch levels in fattening rabbit diets. Journal of Animal Science, Champaign, v. 63, n. 3, p. 1897-1904, 1986.

FANIMO, A. O.; ODUGUWA, O. O.; ALADE, A. A.; OGUNNAIKE, T. O.; ADESEHINWA, A. K. Growth performance, nutrient digestibility of rabbits fed cashew apple waste. Livestock Research for Rural Development, Cali, v. 15, n. 8, p. 22-26, 2003.

FARIA, H. G.; FERREIRA, W. M.; SCAPINELLO, C.; OLIVEIRA, C. E. A. Efeito da utilização de dietas simplificadas, à base de forragem, sobre a digestibilidade e o desempenho de coelhos Nova Zelândia. Revista Brasileira de Zootecnia, Viçosa, MG, v. 37, n. 10, p. 1797-1801, 2008.

FARIAS, L. A.; LOPES, J. B.; FIGUEIRÊDO, A. V.; ALBUQUERQUE, D. M. N.; ARAÚJO NETO, A. A.; RAMOS, L. S. N. Pseudofruto do cajueiro (Anacardium occidentale L.) para suínos em crescimento: metabolismo de nutrientes e desempenho. Ciência Animal Brasileira, Goiânia, v. 9, n. 1, p. 100-109, 2008.

FIALHO, E. T.; BARBOSA, H. P.; FERREIRA, A. S.; GOMES, P. C.; GIROTTO, A. F. Utilização da cevada suplementada com óleo de soja para suínos em crescimento e terminação. Pesquisa Agropecuária Brasileira, Brasília, v. 27, n. 10, p. 1467-1475, 1992.

FREITAS, E. R.; SAKOMURA, N. K.; NEME, R.; SANTOS, A. L.; FERNANDES, J. B. K. Efeito do processamento da soja integral sobre a energia metabolizável e a digestibilidade dos aminoácidos para aves. Revista Brasileira de Zootecnia, Viçosa, MG, v. 34, n. 6, p. 1948-1949, 2005.

GOMES, F. A.; FASSANI, E. J.; RODRIGUES, P. B.; SILVA FILHO, J. C. da. Valores energéticos de alguns alimentos utilizados em rações para codornas japonesas. Revista Brasileira de Zootecnia, Viçosa, MG, v. 36, n. 2, p. 396-402, 2007.

LEITE, D. F. L.; AGUIAR, E. M.; HOLANDA, J. S.; RANGEL, A. H. N.; AURELIANO, I. P. L.; MEDEIROS, V. B.; LIMA JÚNIOR, D. M. Valor nutritivo do resíduo de caju desidratado associado a diferentes concentrados. Acta Veterinaria Brasilica, Mossoró, v. 7, n. 1, p. 66-72, 2013.

LOPES, J. B.; SILVA, M. V. F.; FREITA, A. C.; RAMOS, L. S. N.; FARIAS, L. A. Inclusão do farelo do pseudofruto de caju desidratado (Anacardium occidentale L.) em rações de frangos de corte na fase de acabamento. Revista Cientifica de Produção Animal, Teresina, v. 7, n. 2, p. 44-51, 2005.

LOUSADA JÚNIOR, J. E.; COSTA, J. M. C.; NEIVA, J. M. M.; RODRIGUEZ, N. M. Caracterização físicoquímica de subprodutos obtidos do processamento de frutas tropicais visando seu aproveitamento na alimentação animal. Revista Ciência Agronômica, Fortaleza, v. 37, n. 1, p. 70-76, 2006.

MATTERSON, L. D.; POTTER, L. M.; STUTZ, M. W.; SINGSEN, E. P. The metabolizable energy of feed ingredients for chickens. Research Report, Connecticut: The University of Connecticut, v. 7, n. 1, p. 11-14, 1965.

NERY, L. R.; ALBINO, L. F. T.; ROSTAGNO, H. S.; CAMPOS, A. M. A.; SILVA, C. R. Valores de energia metabolizável de alimentos determinados com frangos de corte. Revista Brasileira de Zootecnia, Viçosa, MG, v. 36, n. 5, p. 1354-1358, 2007.

NGOSHE, A. A.; IGWEBUIKE, J. U.; ADAMU, S. B. Effects of feeding carrot (Daucuscarota L) leaf meal on haematology, blood chemistry and carcass characteristics of growing rabbits in a semi-arid environment of Borno State of Nigeria. Pakistan Journal of Nutrition, Faisalabad, v. 12, n. 1, p. 12-19, 2013.

OLIVEIRA, M. C.; LUI, J. F. Desempenho, características de carcaça e viabilidade econômica de coelhos sexados abatidos em diferentes idades. Arquivo Brasileiro de Medicina Veterinária e Zootecnia, Belo Horizonte, v. 58, n. 6, p. 1149-1155, 2006.

ORTIZ HERNANDEZ, J. A.; RUBIO LOZANO, M. S. Effect of breed and sex on rabbit carcass yield and meat quality. World Rabbit Science, Valência, v. 9, n. 2, p. 51$56,2001$. 
RAMOS, L. S. N.; LOPES, J. B.; FIGUEIRÊDO, A. V.; FREITAS, A. C.; FARIAS, L. A.; SANTOS, L. S.; SILVA, H. O. Polpa de caju em rações para frangos de corte na fase final: desempenho e características de carcaça. Revista Brasileira de Zootecnia, Viçosa, MG, v. 35, n. 3, p. 804-810, 2006.

RAO, D. R.; CHEN, C. P.; SUNKI, G. R.; JOHNSON, W. M. Effect of weaning and slaughter ages on rabbit meat production II. carcass quality and composition. Journal of Animal Science, Champaign, v. 46, n. 3, p. 578-583, 1978.

RETORE, M.; SILVA, L. P.; TOLEDO, G. S. P.; ARAÚJO, I. G.; EGGERS, D. P. Fontes de fibra de coprodutos agroindustriais proteicos para coelhos em crescimento. Ciência Rural, Santa Maria, v. 40, n. 4, p. 963-969, 2010.

SILVA, L. M.; OLIVEIRA, C. H. A.; RODRIGUES, F. V.; RODRIGUES, M. R. C.; BESERRA, F. J.; SILVA, A. M.; LEMOS, J. C.; FERNANDES, A. A. O.; RONDINA, D. Performance in vivo and carcass characteristics of lambs fed with cashew apple bagasse. Archivos de Zootecnia, Córdoba, v. 60, n. 231, p. 777-786, 2011.

SREERAMA, Y. N.; NEELAM, D. A.; SASHIKALA, V. B.; PRATAPE, V. M. Distribution of nutrients and antinutrients in milled fractions of chickpea and horse gram: seed coat phenolics and their distinct modes of enzyme inhibition. Journal of Agricultural and Food Chemistry, Washington, v. 58, n. 7, p. 4322-4330, 2010.

STATISTICAL ANALYSIS SYSTEM - SAS. System for Microsoft Windows. Release 8.2. Cary, 2001.

TELES, M. M.; NEIVA, J. N. M.; CLEMENTINO, R. H.; RÊGO, A. C. D.; CÂNDIDO, M. J. D.; RESTLE, J. Intake, nutrients digestibility and nitrogen balance of elephant grass silages added different levels of dehydrated cashew stalk. Ciência Rural, Santa Maria, v. 40, n. 2, p. 397-403, 2010.

VILLAMIDE, M. J. Methods of energy evaluation of feeds ingredients for rabbits and their accuracy. Animal Feed Science and Technology, Amsterdam, v. 57, n. 3, p. 211-223, 1996. 